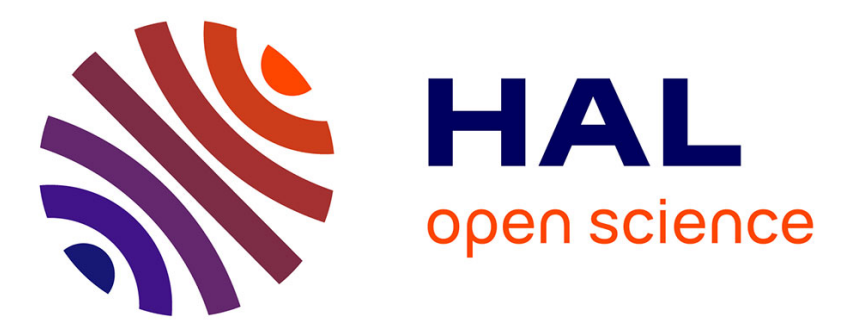

\title{
Cyclopentadienylmolybdenum(VI) and Molybdenum(V) Oxo Chemistry: New Synthetic and Structural Features
}

\author{
Dirk Saurenz, Funda Demirhan, Philippe Richard, Rinaldo Poli, Helmut
} Sitzmann

\section{- To cite this version:}

Dirk Saurenz, Funda Demirhan, Philippe Richard, Rinaldo Poli, Helmut Sitzmann. Cyclopentadienylmolybdenum(VI) and Molybdenum(V) Oxo Chemistry: New Synthetic and Structural Features. European Journal of Inorganic Chemistry, 2002, 2002 (6), pp.1415-1424. 10.1002/10990682(200206)2002:63.0.CO;2-V . hal-03284357

\section{HAL Id: hal-03284357 https://hal.science/hal-03284357}

Submitted on 20 Jul 2021

HAL is a multi-disciplinary open access archive for the deposit and dissemination of scientific research documents, whether they are published or not. The documents may come from teaching and research institutions in France or abroad, or from public or private research centers.
L'archive ouverte pluridisciplinaire HAL, est destinée au dépôt et à la diffusion de documents scientifiques de niveau recherche, publiés ou non, émanant des établissements d'enseignement et de recherche français ou étrangers, des laboratoires publics ou privés. 


\section{European Journal of Inorganic Chemistry}

\section{Cyclopentadienylmolybdenum(VI) and Molybdenum(V) Oxo Chemistry: New Synthetic and Structural Features}

\section{Dirk Saurenz, ${ }^{[\mathrm{a}]}$ Funda Demirhan, ${ }^{[\mathrm{a}, \mathrm{b}]}$ Philippe Richard, ${ }^{[\mathrm{a}]}$ Rinaldo Poli*, ${ }^{[\mathrm{a}]}$ and Helmut Sitzmann ${ }^{[\mathrm{c}]}$}

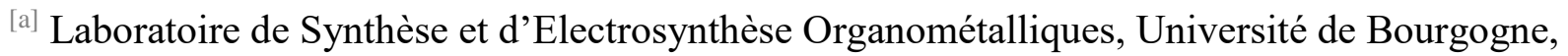
Faculté de Science Gabriel, 6 boulevard Gabriel, 21000 Dijon, France

Fax: +33-03.80.39.37.20

\section{E-mail: Rinaldo.Poli@u-bourgogne.fr}

${ }^{[b]}$ Celal Bayar University, Faculty of Sciences \& Liberal Arts, Department of Chemistry, 45030, Muradiye-Manisa, Turkey

${ }^{[c]}$ Fachbereich Chemie, Universität Kaiserslautern, Erwin-Schrödinger-Str. 54, 67663

Kaiserslautern, Germany

Fax: +49-(0)631-2052187

E-mail: sitzmann@chemie.uni-kl.de

Received 5 November 2001

Molybdenum / Cyclopentienyl ligands / Oxo ligands / X-ray crystallography

Convenient syntheses are described for $\mathrm{Cp}, \mathrm{Cp}^{*}$, and related cyclopentadienyl derivatives $\left({ }^{4} \mathrm{Cp}=\right.$ $\mathrm{C}_{5} \mathrm{HPr}_{4}^{i} ; \mathrm{Cp}^{\prime \prime}=\mathrm{C}_{5} \mathrm{H}_{2} \mathrm{Bu}_{3}^{t}-1,2,4$ ) of formula (Ring) ${ }_{2} \mathrm{Mo}_{2} \mathrm{O}_{5}$. Compound $\mathrm{Cp}_{2} \mathrm{Mo}_{2} \mathrm{O}_{5}$ forms in good yields by the rapid oxidation of red $\left[\mathrm{CpMoO}_{2}\right]_{4}$ with $\mathrm{PhIO}$ in $\mathrm{CH}_{2} \mathrm{Cl}_{2}$. $\mathrm{Cp}^{*}{ }_{2} \mathrm{Mo}_{2} \mathrm{O}_{5}$ is obtained by $\mathrm{CH}_{3} \mathrm{COOH}$ acidification of aqueous solutions of $\mathrm{Cp}^{*} \mathrm{MoO}_{3}{ }^{-} \mathrm{Na}^{+}$, the latter being generated in a single step from $\mathrm{Cp}^{*} \mathrm{MoCl}_{4}$ and $>5$ equiv of aqueous $\mathrm{NaOH}$ in air. Minor amounts of compound $\left[\mathrm{Cp} * \mathrm{MoO}_{2}\right]_{2}$ are also isolated from this reaction but the formation of this by-product may be reduced 
by using a two-step basic hydrolysis procedure. Extension of the latter strategy has also allowed the good yield preparation of ${ }^{4} \mathrm{Cp}_{2} \mathrm{Mo}_{2} \mathrm{O}_{5}, \mathrm{Cp}^{\prime \prime}{ }_{2} \mathrm{Mo}_{2} \mathrm{O}_{5}$, and ${ }^{4} \mathrm{CpMoO}_{2} \mathrm{Cl}$, in addition to the by-product $\left[\mathrm{Cp} " \mathrm{MoO}_{2}\right]_{2}$. X-ray structures are reported for compounds ${ }^{4} \mathrm{Cp}_{2} \mathrm{Mo}_{2} \mathrm{O}_{5}, \mathrm{Cp}^{\prime \prime}{ }_{2} \mathrm{Mo}_{2} \mathrm{O}_{5},\left[\mathrm{Cp}^{*} \mathrm{MoO}_{2}\right]_{2}$, $\left[\mathrm{Cp}^{\prime \prime} \mathrm{MoO}_{2}\right]_{2}$ and ${ }^{4} \mathrm{CpMoO} 2 \mathrm{Cl}$. 


\section{Introduction}

High oxidation state organometallic chemistry has experienced a rapid development in the last 20 years, mostly justified by the search for efficient oxidation catalysts. The half-sandwich oxo derivatives of rhenium, ${ }^{[1-3]}$ displaying a very rich chemical reactivity and catalytic activity, are an example of a well investigated class of compounds. Some of the earliest high oxidation state organometallics, however, are the cyclopentadienyl oxo derivatives of molybdenum, first developed in the laboratory of M. L. H. Green. ${ }^{[4,5]}$

The stability of high oxidation state complexes relies on the presence of electronegative and $\pi$ donating ligands such as the halides or negatively charged oxygen (oxo, alkoxo) or nitrogen (nitrido, imido, amido) based ligands. The organic fragments that are most compatible with this ligand environment are odd-electron ones such as alkyls (1-electron), allyls (3-electron) dienyls (5-electron), etc., while neutral organic fragments (olefins, arenes, etc.) necessitate electron-richer, low-valent metal centers to optimize bonding. These conditions confer a high degree of covalency to the resulting metal-carbon bonds, which consequently become quite resistance to hydrolytic conditions. It is therefore somewhat surprising that the physical behavior and chemical reactivity of high oxidation state organometallics is not systematically investigated in water, although aqueous reagents are sometimes used for their syntheses. This contrasts with the well developed aqueous chemistry of high oxidation state oxomolybdenum complexes. ${ }^{[6,7]}$ On the other hand, the rich electrochemical behavior displayed by the concerned metals, notably molybdenum, makes these molecules quite interesting for potential electrocatalytic applications. For these reasons, we have initiated a research effort aimed at increasing our basic knowledge of the physical properties and chemical reactivity of organomolybdenum compounds in a variety of high oxidation states in water.

Although several investigations of cyclopentadienyl oxo complexes of molybdenum in high oxidation states have been reported, ${ }^{[8,9]}$ the access routes to these material cannot be considered as completely satisfactory. In this first contribution, we shall focus on the improvements of synthetic procedures to access compounds $\mathrm{Cp}_{2} \mathrm{Mo}_{2} \mathrm{O}_{5}$ and $\mathrm{Cp}_{2}{ }_{2} \mathrm{Mo}_{2} \mathrm{O}_{5}$, which we plan to use as starting materials for our studies. In addition, we shall report an extension of the synthetic procedure to analogues containing differently substituted cyclopentadienyl rings. We are interested in cyclopentadienyl rings with a high degree of substitution as they are known to afford more inert metal-cyclopentadienyl bonds by way of disfavoring access to the metal center, while at the same time rendering the other ligands more labile. Interesting reactivity may then be expected. Some basic aqueous chemistry which is related to the optimization of the syntheses reported in this paper will also be discussed. Detailed studies of the behavior of these compounds in water as a function of the $\mathrm{pH}^{[10]}$ and of the electrode potential ${ }^{[11]}$ have also been completed and are being reported separately. 


\section{Results}

\section{The cyclopentadienyl oxo molybdenum(VI) system.}

(a) Discussion of previously reported access routes.

As mentioned in the Introduction, compound $\mathrm{Cp}_{2} \mathrm{Mo}_{2} \mathrm{O}_{5}$ has been known since 1964, but a reliable high yield and practical synthesis does not seem to be yet available. It was first obtained in $20 \%$ yield by the photolytic degradation of $\left[\mathrm{CpMo}(\mathrm{CO})_{3}\right]_{2}$ in chloroform, together with several other products. ${ }^{[4]}$ It also forms in small yields by adventitious oxygenation of solutions of various CpMo derivatives. ${ }^{[4 \text {, }}$ 5] A higher yield synthesis (79\%) was reported by oxidation of the dinuclear $\mathrm{Mo}(\mathrm{V})$ compound $\left[\mathrm{CpMoO}_{2}\right]_{2}$. This, however, requires use of $\mathrm{Ag}_{2} \mathrm{O}$ as the oxygen transfer agent and warming in $\mathrm{CH}_{2} \mathrm{Cl}_{2}$ at $55^{\circ}$ for 1.5 days. ${ }^{[12]}$ The precursor complex, in turn, can be obtained by hydrolysis of $\mathrm{CpMoX}_{4}(\mathrm{X}=\mathrm{Cl}, \mathrm{Br})$ with excess water. A red isomer, formulated as a tetranuclear compound, is obtained immediately while a longer exposure to water or dissolution of the red isomer in acetone or chloroform slowly afford a dinuclear orange isomer. ${ }^{[5,12]}$ A similar evolution was described for analogous compounds with monosubstituted cyclopentadienyl ligands. ${ }^{[12]}$ Since the reported behavior of the red tetrameric form suggests that it is a chemically more labile form, we wondered whether the oxidation of this red isomer by sufficiently rapid oxygen transfer agents might provide an easier and high yield access to the desired Mo(VI) product before its conversion to the less reactive orange isomer.

\section{(b) New synthetic strategy}

Several effective reagents are commonly used for oxygen transfer chemistry, the most easily accessible one being $\mathrm{H}_{2} \mathrm{O}_{2}$. We were hesitant to use this reagent because the formation of peroxo compounds of $\mathrm{Mo}(\mathrm{VI})$ or $\mathrm{W}(\mathrm{VI})$ such as $\mathrm{Cp} * \mathrm{~W}\left(\mathrm{O}_{2}\right)(\mathrm{O}) \mathrm{R},{ }^{[13-15]}$ or $\mathrm{Cp} * \mathrm{M}\left(\mathrm{O}_{2}\right)(\mathrm{O}) \mathrm{Cl}(\mathrm{M}=\mathrm{Mo}, \mathrm{W})^{[16 \text {, }}$ ${ }^{17]}$ by treatment of suitable precursors with either $\mathrm{H}_{2} \mathrm{O}_{2}$ or hydroperoxides had previously been described. In fact, oxidation tests with $\mathrm{H}_{2} \mathrm{O}_{2}$ gave unsatisfactory results. The use of $\mathrm{PhIO},{ }^{[18]}$ on the other hand, provided a rapid and convenient synthesis in two steps ( $>50 \%$ overall yield) from $\mathrm{CpMoCl}_{4}$, which is itself easily prepared from commercially available $\mathrm{Mo}(\mathrm{CO})_{6}$ (Equations 1 and 2) ${ }^{[19]}$ The second step is complete within $15 \mathrm{~min}$ at room temperature and the best results are obtained when the solution is immediately worked up. If the product is allowed to sit in the dichloromethane solution, darker insoluble by-products start to form. The intermediate red $\mathrm{Mo}(\mathrm{V})$ oxo complex must be isolated and removed from water. An attempt to carry through the synthetic procedure without 
this isolation step gave unsatisfactory results. This procedure, however, constitutes a significant improvement over the previously available ones, especially in terms of time efficiency as both steps can be carried out at room temperature and the overall procedure may be accomplished in a half day.

$$
\begin{aligned}
& 4 \mathrm{CpMoCl}_{4}+8 \mathrm{H}_{2} \mathrm{O} \longrightarrow\left[\mathrm{CpMoO}_{2}\right]_{4}+16 \mathrm{HCl} \\
& {\left[\mathrm{CpMoO}_{2}\right]_{4}+2 \mathrm{PhIO} \longrightarrow \mathrm{Cp}_{2} \mathrm{Mo}_{2} \mathrm{O}_{5}+2 \mathrm{PhI}}
\end{aligned}
$$

The procedure described below for the $\mathrm{Cp}^{*}$ and related analogues, via the hitherto unknown $\left[\mathrm{CpMoO}_{3}\right]^{-}$anion, ${ }^{[20]}$ has not given satisfactory results for the $\mathrm{Cp}$ system.

\section{The pentamethylcyclopentadienyl oxo molybdenum(VI) system.}

(a) Discussion of previously reported access routes.

The Cp* compound was first reported in 1985 by Herberhold et al. as the product of the aerial oxidation of $\mathrm{Cp}^{*} \mathrm{Mo}(\mathrm{CO})_{2}(\mathrm{NO})^{[21]}$ and was subsequently shown to form as a small yield by-product from a variety of other reactions. ${ }^{[22-25]}$ A high yield synthesis was reported by Faller and Ma by aerial oxidation of $\left[\mathrm{Cp}^{*} \mathrm{Mo}(\mathrm{CO})_{2}\right]_{2}$ in chloroform, but the product is said to be contaminated by ca. $15 \%$ of the chloride complex $\mathrm{Cp}^{*} \mathrm{MoO}_{2} \mathrm{Cl}$ and needs further exposure to acetone/water for purification, ${ }^{[26]}$ while the synthesis of the starting compound from commercially available $\mathrm{Mo}(\mathrm{CO})_{6}$ is not itself free from pitfalls. ${ }^{[27,28]}$ This reaction was re-examined later by Bottomley and shown to yield a host of other incompletely oxidized products under a variety of conditions. ${ }^{[29,30]}$ The preparation in $70-75 \%$ yield from $\mathrm{Cp}^{*} \mathrm{MoCl}_{4}$ reported by Umakoshi and Isobe ${ }^{[31]}$ is related to the synthetic procedure reported by us here, but was not optimized for large scale syntheses and uses the exotic sodium oxometallate salts $\mathrm{Na}_{2} \mathrm{MoO}_{4}, \mathrm{Na}_{2} \mathrm{WO}_{4}$ or $\mathrm{NaVO}_{3}$ as oxidants. Another reported high yield syntesis is by protonolysis of the unusual starting compound $\mathrm{Cp}^{*} \mathrm{Mo}\left(\mathrm{NBu}^{t}\right)_{2} \mathrm{Cl}$ with aqueous $\mathrm{HCl}^{[32]}$

Finally, work carried out in Geoffroy's laboratory has shown that the hydrolysis of $\mathrm{Cp}^{*} \mathrm{MCl}_{4}(\mathrm{M}=$ $\mathrm{Mo}, \mathrm{W})$ in the presence of an amine $\left(\mathrm{Bu}^{\mathrm{t}} \mathrm{NH}_{2}\right)$ yields $\mathrm{Bu}^{\mathrm{t}} \mathrm{NH}_{3}{ }^{+}\left[\mathrm{Cp}^{*} \mathrm{MO}_{3}\right]^{-}$in good yields, ${ }^{[33]}$ while Sundermeyer has shown that the same anions are also formed upon treatment of the oxo-bridged dimers $\mathrm{Cp}^{*}{ }_{2} \mathrm{M}_{2} \mathrm{O}_{5}$ with tetrabutylammonium hydroxide. ${ }^{[32]}$ The acidification of the anion solution, studied in the Geoffroy study for the tungsten compound, gives back the dinuclear complex via the presumed condensation of initially formed $\mathrm{Cp}^{*} \mathrm{WO}_{2}(\mathrm{OH}) .{ }^{[33]}$

A detailed discussion of this reversible anion/dimer transformation and the aqueous chemistry of the tetrachloride compounds is essential, as it forms the basis of our improved synthetic strategy. Geoffroy et al. have reported that the reaction of $\mathrm{Cp}^{*} \mathrm{MoCl}_{4}$ with 2 equiv of $\mathrm{NaOH}$ in acetone-water in an open flask for more than 30 min gives $\mathrm{Cp}^{*} \mathrm{MoO}_{2} \mathrm{Cl}$, while use of an unspecified excess of $\mathrm{NaOH}$ affords the dinuclear $\mathrm{Cp}_{2}{ }_{2} \mathrm{Mo}_{2} \mathrm{O}_{5}{ }^{[34]}$ The reaction between $\mathrm{Cp}^{*} \mathrm{MoO}_{2} \mathrm{Cl}$ and excess (3 equivalents) 
of $\mathrm{NaOH}$ was also reported to yield the dinuclear compound. These observations seem odd to us in view of the above mentioned Sundermeyer result, which we have confirmed (see next section). ${ }^{[35]}$ In contrast with the apparent lack of reactivity between $\mathrm{Cp}^{*}{ }_{2} \mathrm{Mo}_{2} \mathrm{O}_{5}$ and excess aqueous $\mathrm{NaOH}$, excess aqueous $\mathrm{Bu}^{\mathrm{t}} \mathrm{NH}_{2}$ (a weaker base than $\mathrm{NaOH}$ ) yields $\mathrm{Bu}^{\mathrm{t} N \mathrm{NH}_{3}}{ }^{+}\left[\mathrm{Cp}^{*} \mathrm{MoO}_{3}\right]^{-}$in good yields under analogous conditions. ${ }^{[34]}$ Furthermore, it was shown that the acidification of dichloromethane solutions of the $\mathrm{Bu}^{\mathrm{t} N H_{3}}{ }^{+}\left[\mathrm{Cp}^{*} \mathrm{MoO}_{3}\right]^{-}$salt with acetic acid affords $\mathrm{Cp}^{*}{ }_{2} \mathrm{Mo}_{2} \mathrm{O}_{5}$, which was recovered in 58\% yields. From these observations, it would seem logical to imagine a pH-dependent equilibrium between the anionic mononuclear and the neutral dinuclear forms (Equation 3 ) in water. ${ }^{[36]}$ The anion should therefore be the ultimate product when excess strong base (e.g. $\mathrm{NaOH})$ is present, in contrast to Geoffroy's report. On the basis of this hypothesis, we have developed the new synthetic procedure reported in the following section. Preliminary investigations show that, indeed, yellow $\mathrm{Cp}^{*}{ }_{2} \mathrm{Mo}_{2} \mathrm{O}_{5}$ solutions in $\mathrm{MeOH}-\mathrm{H}_{2} \mathrm{O}$ become nearly colorless upon treatment with $\mathrm{NaOH}$, and the resulting basic solutions turn back yellow upon lowering the $\mathrm{pH}$ by addition of strong acids.

$$
\mathrm{Cp}^{*}{ }_{2} \mathrm{Mo}_{2} \mathrm{O}_{5}+2 \mathrm{OH}^{-} \rightleftarrows 2\left[\mathrm{Cp}^{*} \mathrm{MoO}_{3}\right]^{-}+\mathrm{H}_{2} \mathrm{O}
$$

\section{(b) New synthetic strategy}

The $\mathrm{Cp}^{*} \mathrm{MoCl}_{4}$ compound is conveniently prepared in high yields and purity ${ }^{[37]}$ from commercially available $\mathrm{Mo}(\mathrm{CO})_{6}$ and is therefore the choice starting compounds for our synthetic work. As mentioned in the previous section, it seemed to us that excess $\mathrm{NaOH}$ under aerobic conditions should lead directly to the cyclopentadienyltrioxomolybdate anion, according to the stoichiometry of Equation 4.

$$
2 \mathrm{Cp}^{*} \mathrm{MoCl}_{4}+10 \mathrm{OH}^{-}+1 / 2 \mathrm{O}_{2} \longrightarrow 2\left[\mathrm{Cp}^{*} \mathrm{MoO}_{3}\right]^{-}+8 \mathrm{Cl}^{-}+5 \mathrm{H}_{2} \mathrm{O}
$$

Treatment of acetone solutions of $\mathrm{Cp}^{*} \mathrm{MoCl}_{4}$ with a slight excess (ca. 6 equivalents) of aqueous $\mathrm{NaOH}$ in air for over a day at room temperature yielded a suspension of the pale yellow $\mathrm{Cp}^{*} \mathrm{MoO}_{3}{ }^{-}$ $\mathrm{Na}^{+}$precipitate but also minor quantities of a soluble colored by-product (identified as $\left[\mathrm{Cp}^{*} \mathrm{MoO}_{2}\right]_{2}$, vide infra). Separation of this by-product is accomplished by complete evaporation of the solvent mixture and redissolution in pure water, which dissolves the sodium salt but not the by-product. Since the sodium organomolybdate salt may be difficult to separate by fractional crystallization from $\mathrm{NaCl}$ and excess $\mathrm{NaOH}$, we have proceeded directly to its conversion to the neutral dimer, which is insoluble in pure water. Dropwise addition of acetic acid from a burette leads, after neutralization of the excess base, to the instantaneous precipitation of the yellow product. The acid addition is stopped when the administration of one further drop of the acid solution does not cause any further 
precipitation. The synthetic procedure can therefore be handled as a simple titration reaction allowing the use of close to the stoichiometric amount of acid. This is important because the excess acetic acid is also partially extracted into the ether layer and large quantities of this compound may interfere with the crystallization procedure or even contaminate the organomolybdenum product. This procedure consistently gives a pure product with yields in excess of $60 \%$ on a $2 \mathrm{~g}$ scale. The synthesis can also be accomplished stepwise by reaction of $\mathrm{Cp}^{*} \mathrm{MoCl}_{4}$ with 3 equivalents of $\mathrm{NaOH}$ for 1 day, followed by the addition of 3 more equivalents of $\mathrm{NaOH}$. In this fashion, the formation of the $\mathrm{Mo}(\mathrm{V})$ byproduct is avoided (see discussion). The isolated yield of the desired product, however, is not increased by this modified procedure.

\section{(c) Isolation and structure of the $\left[\mathrm{Cp}^{*} \mathrm{MoO}_{2}\right]_{2}$ by-product.}

The water-insoluble crop generated during the synthetic procedure described above contains orangered crystalline $\left[\mathrm{Cp} * \mathrm{MoO}_{2}\right]_{2}$, which can be recovered in yields up to $20 \%$ depending on the operating conditions. It seems that not only the time of exposure to air but also the relative amount of water and acetone is important to determine the ratio between the $\operatorname{Mo}(\mathrm{V})$ and $\mathrm{Mo}(\mathrm{VI})$ products (see Discussion). Smaller amounts of water seem to favor a greater extent of oxidation. Compound $\left[\mathrm{Cp} * \mathrm{MoO}_{2}\right]_{2}$ has previously been reported and shown to adopt two possible structures which differ by the relative arrangement of the $\mathrm{Cp}^{*}$ and terminal oxo ligands across the central $\mathrm{Mo}(\mu-\mathrm{O})_{2} \mathrm{Mo}$ plane, syn as in $\mathbf{I}^{[38]}$ (like the analogous Cp system) ${ }^{[39]}$ or anti as in II. ${ }^{[40]}$ We have redetermined the structure of the syn form at lower temperature with a better precision. The results have been deposited with the CCDC but, since they do not significantly differ from those of the higher temperature structure, they are not explicitly reported here. The metal-metal distance in the syn polymorph $[2.587(1) \AA]$ is significantly shorter than in the anti polymorph $[2.647(3) \AA],{ }^{[40]}$ certainly because of the butterfly arrangement which allows the metals to approach each other relative to the planar arrangement of the anti isomer. The same situation is found for the $\left[(\mathrm{L})_{2} \mathrm{Mo}_{2} \mathrm{O}_{4}\right]^{2+}(\mathrm{L}=1,5,9-$ triazacyclononane). ${ }^{[41,42]}$

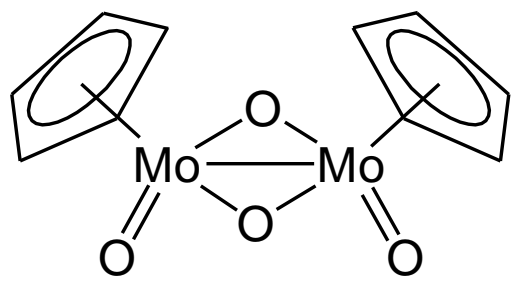

I

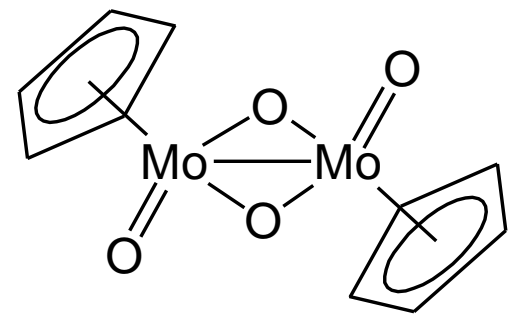

II 


\section{Oxo molybdenum(VI) and molybdenum(V) systems with sterically more encumbering cyclopentadienyl rings.}

\section{(a) Syntheses.}

The procedure described above for the $\mathrm{Cp}$ * system was applied in a straightforward manner to the hydrolysis of ${ }^{4} \mathrm{CpMoCl}_{4}$ and $\mathrm{Cp}^{\text {"' }} \mathrm{MoCl}_{4}$. Again, the aerial hydrolysis affords in both cases solutions containing the water soluble $\mathrm{Na}^{+}\left[(\mathrm{Ring}) \mathrm{MoO}_{3}\right]^{-}$salt. This was not isolated, but its presence is indicated by the identical behavior to the corresponding $\mathrm{Cp}^{*}$ system described above upon acidification. Compounds ${ }^{4} \mathrm{Cp}_{2} \mathrm{Mo}_{2} \mathrm{O}_{5}$ and $\mathrm{Cp}^{\prime}{ }_{2} \mathrm{Mo}_{2} \mathrm{O}_{5}$ were obtained as yellow or yellow-orange crystalline solids that are insoluble in water but soluble in ether. Both were crystallized and their structure was confirmed by X-ray diffraction methods (see next section). They display two IR vibrations that are typical of the $\mathrm{Mo}=\mathrm{O}$ functionalities (symmetric and asymmetric at ca. 885 and 920 $\mathrm{cm}^{-1}$, respectively) and one due to the asymmetric Mo-O-Mo stretch (at ca. $760 \mathrm{~cm}^{-1}$ ), like their $\mathrm{Cp}$ and $\mathrm{Cp}^{*}$ analogues. ${ }^{[4,22]}$

While the ${ }^{4} \mathrm{Cp}$ system afforded the expected dinuclear Mo(VI) product with no indication of incomplete oxidation, the $\mathrm{Cp}$ "' system behaved like the $\mathrm{Cp}^{*}$ system described above and gave also a water insoluble fraction, from which the dinuclear $\mathrm{Mo}(\mathrm{V})$ complex $[\mathrm{Cp} \text { "'MoO}]_{2}$ was recovered. This compound was also characterized by X-ray diffraction methods (see below).

(b) $\mathrm{X}$-ray structures of the (Ring) ${ }_{2} \mathrm{Mo}_{2} \mathrm{O}_{5}$ compounds.

Several X-ray structural determinations have been reported over the years for various polymorphs of $\mathrm{Cp}_{2}{ }_{2} \mathrm{Mo}_{2} \mathrm{O}_{5}{ }^{[23-26]}$ and a discussion of the similarities between them is already available. ${ }^{[25]}$ It is interesting to see whether the steric bulk of the cyclopentadienyl ligand plays any role on the other structural parameters. The geometries of compounds ${ }^{4} \mathrm{Cp}_{2} \mathrm{Mo}_{2} \mathrm{O}_{5}$ and $\mathrm{Cp}^{\prime \prime}{ }_{2} \mathrm{Mo}_{2} \mathrm{O}_{5}$ are shown in Figures 1 and 2, respectively, and the relevant metric data are compared in Table 1 . The ${ }^{4} \mathrm{Cp}$ compound has a symmetry-imposed inversion center on the bridging oxygen atom, but two independent half molecules are contained in the asymmetric unit. The $\mathrm{Cp}^{\prime \prime}$ compound, on the other hand, has a single entire molecule in the asymmetric unit. While the Mo-O-Mo angle is forced to be linear in the first case, it deviates quite substantially from linearity in the second one. This deviation is larger than the largest one previously observed for the related $\mathrm{Cp}^{*}$ polymorphs $\left[172.7(3)^{\circ}\right]$. The $\mathrm{Mo}=\mathrm{O}$ and $\mathrm{Mo}-(\mu-\mathrm{O})$ distances for the $\mathrm{Cp}^{*}$ structures were found to be in the 1.67-1.72 $\AA$ and 1.85$1.90 \AA$ ranges, respectively. The same parameters are within these ranges for both ${ }^{4} \mathrm{Cp}$ and $\mathrm{Cp}^{\prime \prime \prime}$ structures, the Mo- $(\mu-\mathrm{O})$ distances being around the long end of this range in both cases. 


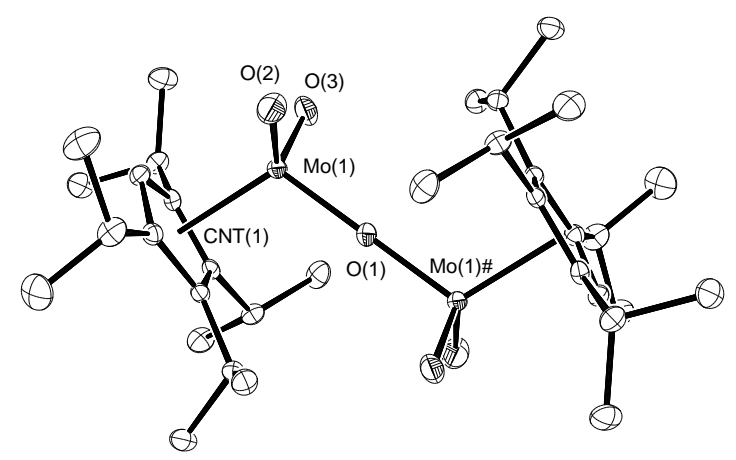

Figure 1. An ORTEP view for one of the two independent molecules of compound ${ }^{4} \mathrm{Cp}_{2} \mathrm{Mo}_{2} \mathrm{O}_{5}$. Ellipsoids are drawn at the $50 \%$ probability level. The atom numbering correspondence for the other molecule is as follows: $\mathrm{Mo}(2)$ for $\mathrm{Mo}(1), \mathrm{O}(4)$ for $\mathrm{O}(1)$, $\mathrm{O}(5)$ for $\mathrm{O}(2), \mathrm{O}(6)$ for $\mathrm{O}(3)$, and $\mathrm{CNT}(2)$ for $\mathrm{CNT}(1)$.

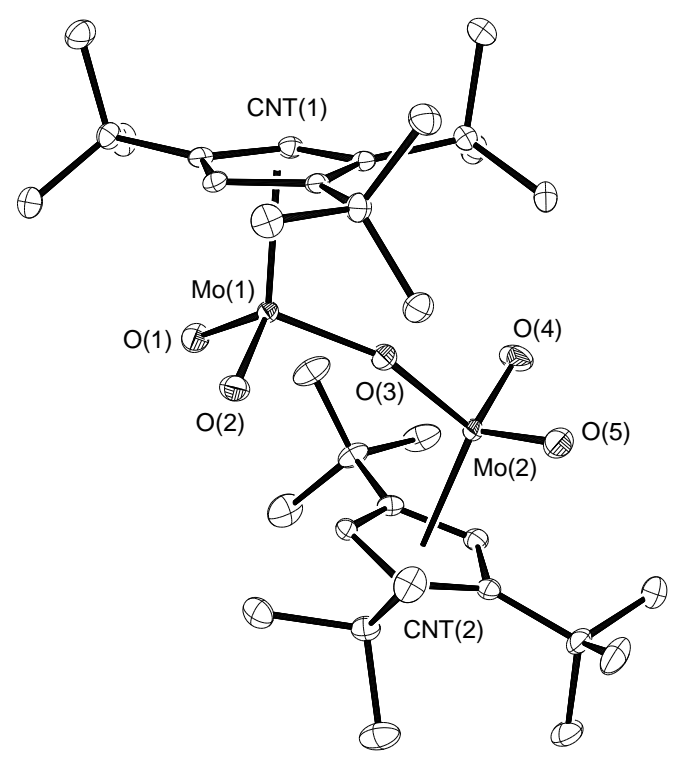

Figure 2. An ORTEP view of compound $\mathrm{Cp}^{\prime \prime}{ }_{2} \mathrm{Mo}_{2} \mathrm{O}_{5}$. Ellipsoids are drawn at the $50 \%$ probability level.

Table 1. Selected bond distances $(\AA)$ and angles $\left({ }^{\circ}\right)$ for compounds $(\operatorname{Ring})_{2} \mathrm{Mo}_{2} \mathrm{O}_{5}\left(\operatorname{Ring}={ }^{4} \mathrm{Cp}\right.$, $\mathrm{Cp}$ "').

\begin{tabular}{lrrrr}
\hline & \multicolumn{3}{c}{} & \multicolumn{3}{c}{$\mathrm{Cp}^{\prime}{ }_{2} \mathrm{Mpo}_{2} \mathrm{O}_{5}$} \\
\hline $\mathrm{Mo}(1)-\mathrm{Mo}{ }_{2} \mathrm{O}_{5}{ }^{\mathrm{a}}$ & & & $1.8950(12)$ \\
& $1.89560(18)$ & $1.89985(17)$ & $\mathrm{Mo}(1)-\mathrm{O}(3)$ & $1.8978(11)$ \\
$\mathrm{Mo}(1)-\mathrm{O}(2)$ & & $\mathrm{Mo}(2)-\mathrm{O}(3)$ & $1.7088(12)$
\end{tabular}




$\begin{array}{llllr}\text { Mo(1)-O(3) } & 1.6969(15) & 1.7034(14) & \mathrm{Mo}(1)-\mathrm{O}(2) & 1.7125(12) \\ & & & \mathrm{Mo}(2)-\mathrm{O}(4) & 1.7101(13) \\ \mathrm{Mo}(1)-\mathrm{CNT}(1) & 2.125(3) & 2.123(3) & \mathrm{Mo}(2)-\mathrm{O}(5) & 1.7050(13) \\ & & & \mathrm{Mo}(2)-\mathrm{CNT}(2) & 2.133(3) \\ \mathrm{O}(1)-\mathrm{Mo}(1)-\mathrm{O}(2) & 103.99(5) & 103.46(5) & \mathrm{O}(1)-\mathrm{Mo}(1)-\mathrm{O}(3) & 103.43(5) \\ \mathrm{O}(1)-\mathrm{Mo}(1)-\mathrm{O}(3) & 102.93(5) & 104.30(5) & \mathrm{O}(2)-\mathrm{Mo}(1)-\mathrm{O}(3) & 104.99(6) \\ & & & \mathrm{O}(3)-\mathrm{Mo}(2)-\mathrm{O}(4) & 103.23(6) \\ & & & \mathrm{O}(3)-\mathrm{Mo}(2)-\mathrm{O}(5) & 102.52(6) \\ \mathrm{O}(2)-\mathrm{Mo}(1)-\mathrm{O}(3) & 106.03(8) & 105.89(8) & \mathrm{O}(1)-\mathrm{Mo}(1)-\mathrm{O}(2) & 104.49(6) \\ & & & \mathrm{O}(4)-\mathrm{Mo}(2)-\mathrm{O}(5) & 104.87(7) \\ \mathrm{CNT}(1)-\mathrm{Mo}(1)-\mathrm{O}(1) & 111.3(2) & 112.3(2) & \mathrm{CNT} 1-\mathrm{Mo}(1)-\mathrm{O}(3) & 111.1(2) \\ & & & \mathrm{CNT} 2-\mathrm{Mo}(2)-\mathrm{O}(3) & 114.0(3) \\ \mathrm{CNT}(1)-\mathrm{Mo}(1)-\mathrm{O}(2) & 114.6(2) & 116.1(2) & \mathrm{CNT} 1-\mathrm{Mo}(1)-\mathrm{O}(1) & 116.9(3) \\ \mathrm{CNT}(1)-\mathrm{Mo}(1)-\mathrm{O}(3) & 116.6(2) & 113.6(2) & \mathrm{CNT} 1-\mathrm{Mo}(1)-\mathrm{O}(2) & 114.5(2) \\ & & & \mathrm{CNT} 2-\mathrm{Mo}(2)-\mathrm{O}(4) & 114.7(3) \\ & & & \mathrm{CNT} 2-\mathrm{Mo}(2)-\mathrm{O}(5) & 115.9(3) \\ \mathrm{Mo}(1)-\mathrm{O}(1)-\mathrm{Mo}(1) \# & 180.0 & 180.0 & \mathrm{Mo}(1)-\mathrm{O}(3)-\mathrm{Mo}(2) & 162.61(7) \\ & & & & \end{array}$

${ }^{\mathrm{a}}$ For the numbering scheme of the second independent molecule (second column), see caption of Figure 1.

(c) X-ray structure of compound $\left[\mathrm{Cp}^{\prime \prime \prime} \mathrm{MoO}_{2}\right]_{2}$.

The geometry of compound $\left[\mathrm{Cp}^{\prime \prime} \mathrm{MoO}_{2}\right]_{2}$ is shown in Figure 3 and selected bonding parameters are reported in Table 2. The immediate striking feature is the relative anti arrangement of the two Cp'" groups, while they are syn for the $\mathrm{Cp}$ analogue and both arrangements are possible for the $\mathrm{Cp}^{*}$ molecule. Although an unambiguous conclusion cannot be drawn, it seems reasonable to imagine that the steric bulk of the $\mathrm{Cp}$ "' ligand enforces the anti arrangement, while the compound might prefer the syn arrangement for electronic reason. Therefore, the syn arrangement will be observed in the less crowded cases (e.g. Cp). It is easy to imagine how the placement of two $\mathrm{Cp}^{\prime \prime}$ ligands into the syn structure (see drawing I) would introduce a severe strain in the molecule. 


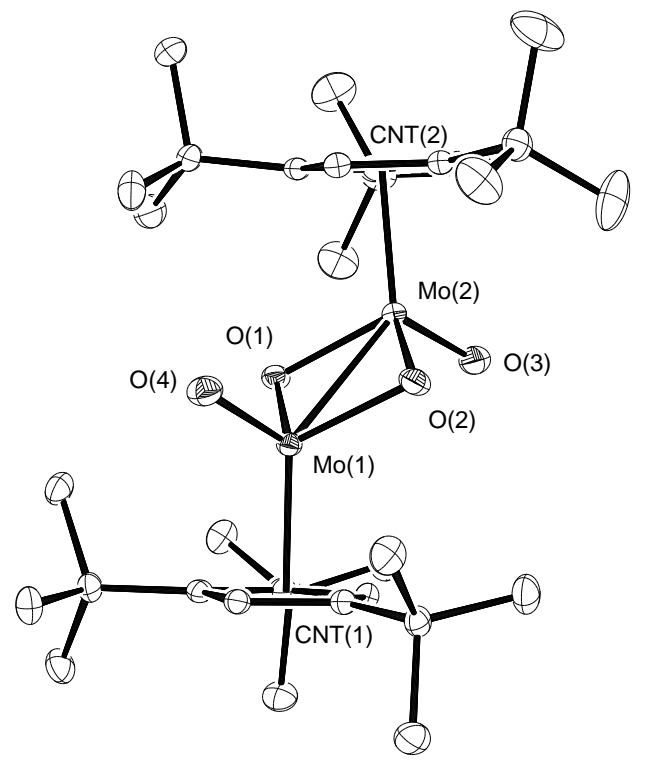

Figure 3. An ORTEP view of compound $\left[\mathrm{Cp}^{\prime \prime} \mathrm{MoO}\right]_{2}$. Ellipsoids are drawn at the $50 \%$ probability level.

Table 2. Selected bond distances $(\AA)$ and angles $\left(^{\circ}\right)$ for compound $\left[\mathrm{Cp}^{\prime \prime} \mathrm{MoO}\right]_{2}$.

\begin{tabular}{lclc}
\hline $\mathrm{Mo}(1)-\mathrm{Mo}(2)$ & $2.65115(19)$ & $\mathrm{CNT}(2)-\mathrm{Mo}(2)-\mathrm{Mo}(1)$ & $127.7(1)$ \\
$\mathrm{Mo}(1)-\mathrm{CNT}(1)$ & $2.082(2)$ & $\mathrm{CNT}(1)-\mathrm{Mo}(1)-\mathrm{O}(1)$ & $114.5(1)$ \\
$\mathrm{Mo}(2)-\mathrm{CNT}(2)$ & $2.082(1)$ & $\mathrm{CNT}(2)-\mathrm{Mo}(2)-\mathrm{O}(1)$ & $113.1(1)$ \\
$\mathrm{Mo}(1)-\mathrm{O}(1)$ & $1.9475(11)$ & $\mathrm{CNT}(1)-\mathrm{Mo}(1)-\mathrm{O}(2)$ & $117.8(1)$ \\
$\mathrm{Mo}(2)-\mathrm{O}(1)$ & $1.9428(11)$ & $\mathrm{CNT}(2)-\mathrm{Mo}(2)-\mathrm{O}(2)$ & $117.5(1)$ \\
$\mathrm{Mo}(1)-\mathrm{O}(2)$ & $1.9464(11)$ & $\mathrm{CNT}(1)-\mathrm{Mo}(1)-\mathrm{O}(4)$ & $116.7(2)$ \\
$\mathrm{Mo}(2)-\mathrm{O}(2)$ & $1.9488(11)$ & $\mathrm{CNT}(2)-\mathrm{Mo}(2)-\mathrm{O}(3)$ & $117.3(2)$ \\
$\mathrm{Mo}(1)-\mathrm{O}(4)$ & $1.7045(12)$ & $\mathrm{O}(2)-\mathrm{Mo}(1)-\mathrm{O}(1)$ & $94.09(5)$ \\
$\mathrm{Mo}(2)-\mathrm{O}(3)$ & $1.7063(12)$ & $\mathrm{O}(1)-\mathrm{Mo}(2)-\mathrm{O}(2)$ & $94.16(5)$ \\
$\mathrm{Mo}(2)-\mathrm{Mo}(1)-\mathrm{O}(1)$ & $46.97(3)$ & $\mathrm{O}(1)-\mathrm{Mo}(1)-\mathrm{O}(4)$ & $106.20(5)$ \\
$\mathrm{Mo}(1)-\mathrm{Mo}(2)-\mathrm{O}(1)$ & $47.11(3)$ & $\mathrm{O}(1)-\mathrm{Mo}(2)-\mathrm{O}(3)$ & $106.94(5)$ \\
$\mathrm{Mo}(2)-\mathrm{Mo}(1)-\mathrm{O}(2)$ & $47.15(3)$ & $\mathrm{O}(2)-\mathrm{Mo}(1)-\mathrm{O}(4)$ & $104.64(5)$ \\
$\mathrm{Mo}(1)-\mathrm{Mo}(2)-\mathrm{O}(2)$ & $47.07(3)$ & $\mathrm{O}(2)-\mathrm{Mo}(2)-\mathrm{O}(3)$ & $105.06(6)$ \\
$\mathrm{Mo}(2)-\mathrm{Mo}(1)-\mathrm{O}(4)$ & $111.79(4)$ & $\mathrm{Mo}(1)-\mathrm{O}(1)-\mathrm{Mo}(2)$ & $85.92(4)$ \\
$\mathrm{Mo}(1)-\mathrm{Mo}(2)-\mathrm{O}(3)$ & $115.06(4)$ & $\mathrm{Mo}(1)-\mathrm{O}(2)-\mathrm{Mo}(2)$ & $85.78(4)$ \\
$\mathrm{CNT}(1)-\mathrm{Mo}(1)-\mathrm{Mo}(2)$ & $131.5(2)$ & & \\
\hline
\end{tabular}


The Mo-Mo distance in compound $\left[\mathrm{Cp}^{\prime \prime} \mathrm{MoO}_{2}\right]_{2}$ compares quite well with that in the anti form of $\left[\mathrm{Cp}^{*} \mathrm{MoO}_{2}\right]_{2}[2.647(3) \AA] .{ }^{[40]}$ This parameter is therefore much more sensitive to the geometry of the central $\mathrm{Mo}_{2} \mathrm{O}_{2}$ moiety (bent for the syn and planar for the anti) than to the type of cyclopentadienyl ring. The $\mathrm{Mo}=\mathrm{O}$ and $\mathrm{Mo}-(\mu-\mathrm{O})$ distances do not seem sensitive to either effect, being essentially identical with those of all other previously described molecules with this stoichiometry, whether of syn or anti type.

\section{The ${ }^{4} \mathrm{CpMoO}_{2} \mathrm{Cl}$ system.}

According to the previous $\mathrm{Cp}^{*}$ literature, ${ }^{[34]}$ the aerobic hydrolysis of the tetrachloro compound with 2 equivalents of aqueous $\mathrm{NaOH}$ leads directly to the corresponding dioxochloro derivative. For the less electron-rich $\mathrm{Cp}$ system, on the other hand, excess water yields quite rapidly the dioxo system as seen above even in the absence of base. ${ }^{[5]}$ The ${ }^{4} \mathrm{Cp}$ system behaves similarly to the $\mathrm{Cp} *$ with which it is sterically and electronically more similar. Identical yields of ${ }^{4} \mathrm{CpMoO}_{2} \mathrm{Cl}$ were obtained when ${ }^{4} \mathrm{CpMoCl}_{4}$ was hydrolyzed in the presence of either 3 or 2 equivalents of $\mathrm{NaOH}$. The compound shows essentially identical $\mathrm{Mo}=\mathrm{O}$ stretching vibrations in the IR spectrum as the related oxo-bridged dinuclear complex and no band in the Mo-O-Mo stretching region, as expected. The structure of this product has also been confirmed by X-ray crystallography (see Figure 4). The relevant bond distances and angles are reported in Table 3. While no structure for a (Ring) $\mathrm{MoO}_{2} \mathrm{X}(\mathrm{X}=\mathrm{Cl}$ or other halogen) seem to be reported, related structures are those of $\left\{\mathrm{C}_{5} \mathrm{Ph}_{4}\left[\mathrm{C}_{6} \mathrm{H}_{3}(\mathrm{OMe})_{2}-2,5\right]\right\} \mathrm{MoO}_{2}(\mathrm{OMe})^{[43]}$ and $\mathrm{Cp} * \mathrm{MoO}_{2}\left[\left(2,6-\mathrm{Pr}_{2}{ }_{2} \mathrm{C}_{6} \mathrm{H}_{3}\right) \mathrm{N}\left(\mathrm{SiMe}_{3}\right)\right]_{2} \mathrm{Si}_{2} \mathrm{O}_{2}(\mathrm{OH})_{3} \cdot{ }^{[44]}$ The $\mathrm{Mo}=\mathrm{O}$ distances are quite comparable in all these compounds. The Mo- $\mathrm{Cl}$ distance compares with related $\mathrm{Mo}(\mathrm{V})-\mathrm{Cl}$ distances and appears to be affected mostly by the cyclopentadienyl ring steric pressure, as suggested by the comparison of the following examples: [Cp*MoOCl] ${ }_{2} \mathrm{O}: 2.368(2) \AA \AA^{[31]} \mathrm{CpMoOCl}_{2}:$ 2.301(4) $\AA$ (average); ${ }^{[45]}$ $\mathrm{Cp}^{*} \mathrm{MoOCl}_{2}: 2.245(9)$ and $2.330(5) \AA$ (averages) in two independent reports. ${ }^{[30,46]}$

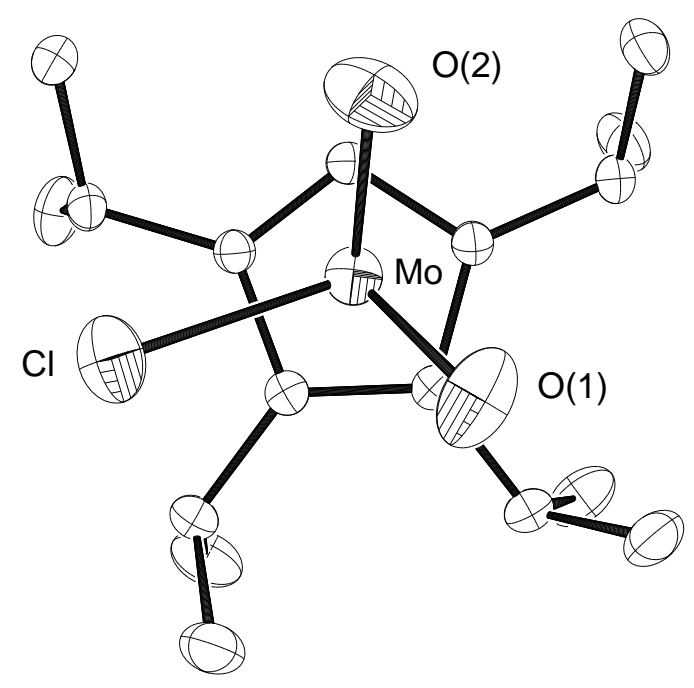


Figure 4. An ORTEP view of compound ${ }^{4} \mathrm{CpMoO}_{2} \mathrm{Cl}$. Ellipsoids are drawn at the $50 \%$ probability level.

Table 3. Selected bond distances $(\AA)$ and angles $\left({ }^{\circ}\right)$ for compound ${ }^{4} \mathrm{CpMoO}_{2} \mathrm{Cl}$.

\begin{tabular}{llll}
\hline Mo-Cl & $2.3251(7)$ & Cl-Mo-O(2) & $101.54(8)$ \\
Mo-O(1) & $1.720(2)$ & Cl-Mo-CNT & $108.8(2)$ \\
Mo-O(2) & $1.700(2)$ & O(1)-Mo-O(2) & $106.83(11)$ \\
Mo-CNT & $2.113(3)$ & O(1)-Mo-CNT & $118.1(2)$ \\
Cl-Mo-O(1) & $102.15(8)$ & O(2)-Mo-CNT & $117.2(3)$ \\
\hline
\end{tabular}

\section{Discussion}

From the previous literature reports and from our results, the following simplified picture emerges for the aerobic hydrolysis of (Ring) $\mathrm{MoCl}_{4}$ compounds (see Scheme 1). Hydrolysis of the first two Mo-Cl bonds leads to (Ring) $\mathrm{MoOCl}_{2}$, which can proceed either to further hydrolysis leading to [(Ring) $\left.\mathrm{MoO}_{2}\right]_{2}$ or it may be oxidized to (Ring) $\mathrm{MoO}_{2} \mathrm{Cl}$. Finally, the dioxo $\mathrm{Mo}(\mathrm{V})$ dimer can be oxidized and the chlorodioxo Mo(VI) complex can be hydrolyzed, in both cases leading to (Ring) ${ }_{2} \mathrm{Mo}_{2} \mathrm{O}_{5}$. Under basic conditions, however, the final product converts to the $\left[(\mathrm{Ring}) \mathrm{MoO}_{3}\right]^{-}$ anion. Of course, other intermediates must also form during these transformations, notably hydroxo complexes whose relative stability is supported by some evidence. ${ }^{[12,31,34]}$

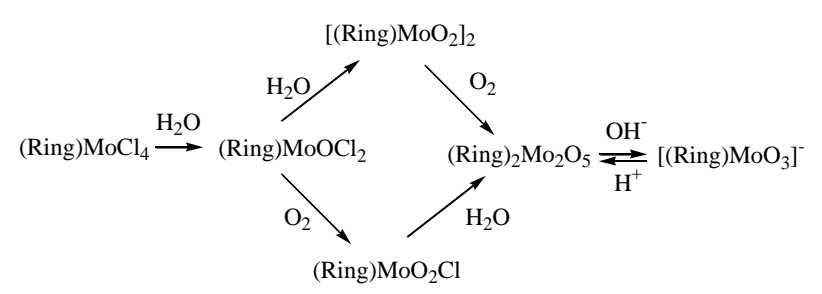

\section{Scheme 1}

If hydrolysis prevails over oxidation at the level of the first dichlorooxo intermediate leading to the dinuclear, metal-metal bonded dioxo compound [(Ring) $\left.\mathrm{MoO}_{2}\right]_{2}$, further oxidization by dioxygen to the Mo(VI) dimer is rather difficult. This is what happens for the simple Cp system. In fact, even oxygen delivering agents such as $\mathrm{Ag}_{2} \mathrm{O}$ react with it slowly. ${ }^{[12]}$ However, the kinetic red form is more reactive and a successful strategy for the formation of $\mathrm{Cp}_{2} \mathrm{Mo}_{2} \mathrm{O}_{5}$ via this route by using $\mathrm{PhIO}$ has been presented in this paper. 
The rate of hydrolysis seems to decrease as the steric bulk of the cyclopentadienyl ring increases. The greater donating power of the bulkier rings may also retard the complete hydrolysis for electronic reasons. The oxidation of the dichlorooxo $\mathrm{Mo}(\mathrm{V})$ species, on the other hand, should be made more favourable by electron-richer ligands. At any rate, the oxidation step may then prevail over hydrolysis leading to the chlorodioxo Mo(VI) species provided there is dioxygen available. This is the situation encountered for the $\mathrm{Cp}^{*}$ system, for which the aerobic hydrolysis in the presence of 2 equiv of $\mathrm{NaOH}$ was reported to give a good yield of $\mathrm{Cp} * \mathrm{MoO}_{2} \mathrm{Cl}^{[34]}$ The same occurs also for the ${ }^{4} \mathrm{Cp}$ system reported here with either 2 or 3 equivalents of $\mathrm{NaOH}$. The use of neutral aqueous conditions should produce 3 acid equivalents as shown in Equation 5. Evidently, the last chloride ligand is not hydrolyzed under neutral conditions, whereas at high $\mathrm{pH}$ (excess $\mathrm{NaOH})$ the only recovered product (after acification) is ${ }^{4} \mathrm{Cp}_{2} \mathrm{Mo}_{2} \mathrm{O}_{5}$.

$2{ }^{4} \mathrm{CpMoCl}_{4}+3 \mathrm{H}_{2} \mathrm{O}+1 / 2 \mathrm{O}_{2} \longrightarrow 2{ }^{4} \mathrm{CpMoO}_{2} \mathrm{Cl}+6 \mathrm{Cl}^{-}+6 \mathrm{H}^{+}$

The relative rate of hydrolysis and oxidation for ( $\mathrm{Ring}) \mathrm{MoOCl}_{2}$ should depend also on other factors such as the concentration of water, the nature of the organic solvent, and the $\mathrm{pH}$. Although we have not carried out a comprehensive study of these effects, we do have qualitative indications that more $\mathrm{Mo}(\mathrm{V})$ dimer complex is obtained when using a larger amount of water for the $\mathrm{Cp}^{*}$ and $\mathrm{Cp}$ "' systems. If Scheme 1 is valid, one would expect that a greater concentration of $\mathrm{OH}^{-}$(larger $\mathrm{NaOH}$ excess) should favor the hydrolysis pathway leading to the $\left[(\mathrm{Ring}) \mathrm{MoO}_{2}\right]_{2}$ system. Indeed, we do obtain a significant amount of this compound as a by-product when the hydrolysis is carried out in the presence of $>5$ equivalents of $\mathrm{NaOH}$, whereas a good yield of $\mathrm{Cp}^{*} \mathrm{MoO}_{2} \mathrm{Cl}$ was obtained by Geoffroy et al. by using only 2 equivalents, with no mention of the formation of the $\mathrm{Mo}(\mathrm{V})$ product. ${ }^{[34]}$ Indeed, repeating the synthesis of $\mathrm{Cp}^{*}{ }_{2} \mathrm{Mo}_{2} \mathrm{O}_{5}$ by stepwise addition of 3 equivalents of $\mathrm{NaOH}$, followed by three more equivalents a day later (without isolation of the intermediate $\mathrm{Cp} * \mathrm{MoO}_{2} \mathrm{Cl}$ complex) completely avoided the formation of the $\left[\mathrm{Cp} * \mathrm{MoO}_{2}\right]_{2}$ by-product. Some subtleties, however, are not yet completely understood. For instance, the Mo(V) dimer was obtained for the $\mathrm{Cp}^{\prime \prime}$ system like for the $\mathrm{Cp}^{*}$ system, but an analogous product was not obtained for the ${ }^{4} \mathrm{Cp}$ system, even when using 5 equiv of $\mathrm{NaOH}$. The use of excess $\mathrm{NaOH}$, however, provided that the oxidation route is followed, allows access to the water soluble sodium salts of ( $\mathrm{Ring}) \mathrm{MoO}_{3}$. Although we have not isolated and characterized the new anions of this type for the ${ }^{4} \mathrm{Cp}$ and $\mathrm{Cp} " '$ systems, their formation is indicated by the protonation reactivity which is identical with that of the $\mathrm{Cp}^{*}$ system: acidification of the water solutions yields the yellow water insoluble (Ring) ${ }_{2} \mathrm{Mo}_{2} \mathrm{O}_{5}$ products. $^{[36]}$ 


\section{Conclusion}

High oxidation state monocyclopentadienyl oxo derivatives of molybdenum are often the end products of oxidative decompositions of lower valent derivatives and were previously available only in low yields or by using impractical starting materials and/or reagents. The hydrolytic route from the easily accessible cyclopentadienylmolybdenum(V) tetrachlorides has been optimized and extended to the preparation of new compounds with sterically more encumbering rings. The stability of these compounds in air and aqueous media makes the exploration of their aqueous chemistry and electrochemistry possible. Investigations in those directions are ongoing in our laboratory.

\section{Experimental Section}

General Remarks: All reactions were carried out in a Jacomex glove box or by the use of standard Schlenk techniques under an argon atmosphere. The solvents were dried by conventional methods $\left(\mathrm{THF}, \mathrm{Et}_{2} \mathrm{O}\right.$, heptane and pentane from sodium benzophenone ketyl and $\mathrm{CH}_{2} \mathrm{Cl}_{2}$ from $\mathrm{P}_{4} \mathrm{O}_{10}$ ) and distilled under argon prior to use. EPR measurements were carried out at the X-band microwave frequency on a Bruker ESP300 spectrometer. The spectrometer frequency was calibrated with DPPH $(g=2.0037)$. ${ }^{1} \mathrm{H}$ NMR spectra were recorded using a Bruker AC-200 and referenced to the residual solvent protons of the deuterated solvent. The elemental analyses were carried out by the analytical service of the Laboratoire de Synthèse et d'Electrosynthèse Organométallique with a Fisons EA 1108 apparatus. Compounds (Ring) $\mathrm{MoCl}_{4}\left(\mathrm{Ring}=\mathrm{Cp}, \mathrm{Cp} *\right.$ and ${ }^{4} \mathrm{Cp}$ ) were prepared as described in the literature. ${ }^{[19,37,47]}$ Compound $\mathrm{Cp}^{\text {"'MoCl}} \mathrm{M}_{4}$ was prepared by a straightforward adaptation of those procedures as described below.

Tetrachloro(1,2,4-tri-tert-butylcyclopentadienyl)molybdenum(V), Cp"'MoCl 4 : $\mathrm{Mo}(\mathrm{CO})_{6}(2.64 \mathrm{~g}, 10.0 \mathrm{mmol})$ and Cp"'Na (2.66 g , $10.3 \mathrm{mmol})$ were mixed as solids and suspended in $40 \mathrm{ml}$ THF. The suspension turned to an orange solution during a $10 \mathrm{~min}$ period. It was then refluxed for $18 \mathrm{~h}$. An IR monitoring indicated the formation of $\mathrm{Cp}$ "'Mo(CO) ${ }_{3}{ }^{-} \mathrm{Na}^{+}$(strong peaks at 1885, 1784 and $1736 \mathrm{~cm}^{-1}$, comparable with literature values for the $\mathrm{Cp}^{*}$ analogue). After cooling to room temperature, $\mathrm{MeI}(700 \mu \mathrm{l}, 11.25 \mathrm{mmol})$ was added to the deep orange-red solution causing darkening to brown. After an additional reflux for $3 \mathrm{~h}$ the solvent was removed in vacuo leaving a yellow brown residue which was extracted in $60 \mathrm{ml} \mathrm{CH}{ }_{2} \mathrm{Cl}_{2}$. After filtration, the deep orange solution was evaporated to dryness yielding 4.13 $\mathrm{g}(9.64 \mathrm{mmol} ; 96.4 \%)$ of yellow brown [Cp"'Mo(CO) $\left.)_{3} \mathrm{Me}\right]$.

A portion of this product, $(3.11 \mathrm{~g}, 7.26 \mathrm{mmol})$ was dissolved in $40 \mathrm{ml} \mathrm{CH} \mathrm{Cl}_{2}$. A suspension of $4.99 \mathrm{~g}(18.2 \mathrm{mmol})$ $\mathrm{PhICl}_{2}$ in $50 \mathrm{ml} \mathrm{CH} \mathrm{Cl}_{2}$ was added in small portions causing a darkening of the orange brown solution to brown and then to deep violet with vigorous $\mathrm{CO}$ evolution. After reflux for $90 \mathrm{~min}$, the mixture was cooled to room temperature and evaporated to dryness. The violet black residue was washed with $2 \times 20 \mathrm{ml}$ pentane to remove the iodobenzene byproduct. The deep violet solid $\mathrm{Cp}^{\prime \prime} \mathrm{MoCl}_{4}$ was dried in vacuo. Yield $3.21 \mathrm{~g}$, (93.7 \%). Elem. Anal.: Calcd for $\mathrm{C}_{17} \mathrm{H}_{29} \mathrm{Cl}_{4} \mathrm{Mo}: \mathrm{C}, 43.34 ; \mathrm{H}, 6.20 \%$. Found: C, 43.57; H, 6.44 \%. EPR $\left(\mathrm{CH}_{2} \mathrm{Cl}_{2}\right): \mathrm{g}=1.99$, a 
Tetraoxo- $\mu$-oxodicyclopentadienyldimolybdenum(VI), $\mathbf{C p}_{2} \mathbf{M o}_{2} \mathrm{O}_{5}$ : Compound $\mathrm{CpMoCl}_{4}(0.555 \mathrm{~g}, 1.83 \mathrm{mmol})$ was added to a flask containing distilled water $(10 \mathrm{ml})$. Shaking of the resulting suspension for a few minutes gave rise to the formation of fine deep red microcrystals. The product $\left(\left\{\mathrm{CpMoO}_{2}\right\}_{4}\right)^{[12]}$ was separated by decanting off the mother liquor, washed with water $(3 \times 10 \mathrm{~mL})$ and quickly with acetone $(5 \mathrm{~mL})$, and dried in vacuo for $2 \mathrm{~h}$ (yield $0.28 \mathrm{~g}, 79.5 \%$ ). This material (1.45 mmol of Mo) was then dissolved in dichloromethane (ca. $100 \mathrm{~mL}$ ) and to the resulting solution was added solid PhIO (0.22 g, $1.0 \mathrm{mmol})$. The mixture was stirred at room temperature for $15 \mathrm{~m}$, resulting in a color change from red to yellow. A longer reaction time should be avoided as it affords larger amounts of insoluble by-products. The solution was filtered and the filtrate was evaporated to give yellow microcrystals. The product was purified by recrystallization from $\mathrm{CH}_{2} \mathrm{Cl}_{2} /$ pentane, and dried in vacuo. Yield $0.207 \mathrm{~g}, 71.1 \%\left(56.5 \%\right.$ from $\left.\mathrm{CpMoCl}_{4}\right)$. The analytical (IR, NMR) properties of the compound correspond to those reported in the literature ${ }^{[4]}$ and confirm its purity.

\section{Tetraoxo- $\mu$-oxobis(pentamethylcyclopentadienyl)dimolybdenum(VI), $\mathrm{Cp}_{2}{ }_{2} \mathrm{Mo}_{2} \mathrm{O}_{5}$ and Dioxodi- $\mu$ -}

oxobis(pentamethylcyclopentadienyl)dimolybdenum(V), [Cp*MoO2] 2. Deep violet $\mathrm{Cp}^{*} \mathrm{MoCl}_{4}(3.48 \mathrm{~g} ; 9.33 \mathrm{mmol})$ was added to a stirred solution of aqueous $\mathrm{NaOH}(19 \mathrm{~mL} ; 3 \mathrm{M} ; 57 \mathrm{mmol})$ in acetone $(200 \mathrm{~mL})$ in an open beaker. The resulting dark brown suspension was stirred for $18 \mathrm{~h}$ causing a lightening of the colour to orange and the precipitation of a pale yellow solid. After evaporation to dryness the brownish residue was extracted in $75 \mathrm{ml}$ of distilled water and filtered. The pale yellow filtrate was acidified with diluted glacial acetic acid causing precipitation of a yellow solid at pH 3.8 - 4.0. The acetic acid addition was stopped when the addition of one further drop did not cause any additional precipitation. The precipitate was extracted with 4x100 ml portions of ether, the last extract being colourless. The combined organic layers were washed with distilled water and dried over $\mathrm{MgSO}_{4}$ overnight. Evaporation of the solvent yielded $1.55 \mathrm{~g}(2.86 \mathrm{mmol} ; 61.3 \%)$ of $\left[\left(\mathrm{Cp}^{*} \mathrm{MoO}_{2}\right)_{2} \mathrm{O}\right]$ as a yellow solid. The ${ }^{1} \mathrm{H}$ NMR spectrum of this compound (singlet at $2.01 \mathrm{ppm}$ in $\mathrm{CDCl}_{3}$ ) corresponds with that described in the literature. ${ }^{[26]}$

From another experiment starting from $2.03 \mathrm{~g}$ of $\mathrm{Cp}^{*} \mathrm{MoCl}_{4}$, the water insoluble orange-red solid remaining from the water extraction was also worked up. It was washed with $20 \mathrm{ml}$ ether then with $20 \mathrm{ml}$ pentane and dried in vacuo affording the dinuclear $\mathrm{Mo}(\mathrm{V})$ compound $\left[\left(\mathrm{Cp}^{*} \mathrm{MoO}_{2}\right)_{2}\right]$ as a orange crystalline solid $(192 \mathrm{mg}, 0.37 \mathrm{mmol} ; 13.6 \%)$. Elem. Anal.: Calcd for $\mathrm{C}_{10} \mathrm{H}_{15} \mathrm{MoO}_{2}: \mathrm{C}, 45.64 ; \mathrm{H}, 5.74 \%$. Found: $\mathrm{C}, 45.36 ; \mathrm{H}, 5.71 \%$. The ${ }^{1} \mathrm{H}$ NMR spectrum (1.98 ppm in $\mathrm{CDCl}_{3}$ ) corresponds with that reported in the literature. ${ }^{[38]}$ Suitable single crystals for $\mathrm{x}$-ray diffraction could be grown by layering a saturated THF solution with heptane at room temperature. Normally up to ca. $20 \%$ of this byproduct was recovered depending on the reaction conditions.

Tetraoxo- $\mu$-oxobis(tetraisopropylcyclopentadienyl)dimolybdenum(VI), ${ }^{4} \mathrm{Cp}_{2} \mathrm{Moz}_{2} \mathrm{O}_{5}$. To a stirred mixture of acetone $(75 \mathrm{~mL})$, THF $(75 \mathrm{~mL})$ and aqueous $\mathrm{NaOH}(2.6 \mathrm{~mL}, 3 \mathrm{M}, 7.8 \mathrm{mmol})$ in an open beaker was quickly added deep purple ${ }^{4} \mathrm{CpMoCl}_{4}$ as a solid (609 mg, $1.29 \mathrm{mmol}$ ). A brown suspension immediately formed which lightened to orange yellow over a period of $2 \mathrm{~h}$. After stirring overnight the solvents were evaporated and the resulting yellow residue was extracted with $100 \mathrm{ml}$ of warm water $\left(50^{\circ} \mathrm{C}\right)$. After filtration the aqueous phase was acidified with diluted glacial acetic acid as described in the previous section causing the precipitation of a yellow solid at $\mathrm{pH} 4$. Extraction of this solid with 3x100 ml portions of ether, followed by separation of the organic layer, washing with water and drying over $\mathrm{MgSO}_{4}$ yielded a yellow ether solution, which was allowed to stand overnight and then was evaporated to dryness to yield $222 \mathrm{mg}(0,3 \mathrm{mmol} ; 46.6 \%)$ of yellow $\left[\left({ }^{4} \mathrm{CpMoO}_{2}\right)_{2} \mathrm{O}\right]$. Elem. Anal.: Calcd for $\mathrm{C}_{34} \mathrm{H}_{58} \mathrm{Mo}_{2} \mathrm{O}_{5}$ : $\mathrm{C}, 55.28 ; \mathrm{H}, 7.91$ \%. Found: C, 54.69; H, $8.25 \%$. IR (Nujol mull): 919s, 889s, 760s cm ${ }^{-1} .{ }^{1} \mathrm{H}$ NMR $\left(\mathrm{CDCl}_{3}\right): 6.01 \mathrm{ppm}(\mathrm{s}, 1 \mathrm{H}$, ring-H), $3.10 \mathrm{ppm}(\mathrm{m}, 4 \mathrm{H}, \mathrm{CHMe} 2), 1.39 \mathrm{ppm}\left(\mathrm{d}, 6 \mathrm{H}, \mathrm{J}_{\mathrm{HH}}=7.3 \mathrm{~Hz}, \mathrm{CH}\left(\mathrm{CH}_{3}\right)_{2}\right), 1,30 \mathrm{ppm}\left(\mathrm{d}, 12 \mathrm{H}, \mathrm{J}_{\mathrm{HH}}=7.3 \mathrm{~Hz}, \mathrm{CH}(\mathrm{CH})_{2}\right)$, 
$1.19 \mathrm{ppm}\left(\mathrm{d}, 6 \mathrm{H}, \mathrm{J}_{\mathrm{HH}}=6.7 \mathrm{~Hz}, \mathrm{CH}\left(\mathrm{CH}_{3}\right)_{2}\right) .{ }^{1} \mathrm{H} \mathrm{NMR}\left(\mathrm{C}_{6} \mathrm{D}_{6}\right): 6.14 \mathrm{ppm}(\mathrm{s}, 1 \mathrm{H}$, ring-H), $3.14 \mathrm{ppm}(\mathrm{m}, 4 \mathrm{H}, \mathrm{CHMe} 2)$, $1.47 \mathrm{ppm}\left(\mathrm{d}, 6 \mathrm{H}, \mathrm{J}_{\mathrm{HH}}=6.7 \mathrm{~Hz}, \mathrm{CH}\left(\mathrm{CH}_{3}\right)_{2}\right), 1.44 \mathrm{ppm}\left(\mathrm{d}, 6 \mathrm{H}, \mathrm{J}_{\mathrm{HH}}=7.0 \mathrm{~Hz}, \mathrm{CH}\left(\mathrm{CH}_{3}\right)_{2}\right), 1.23 \mathrm{ppm}\left(\mathrm{d}, 6 \mathrm{H}, \mathrm{J}_{\mathrm{HH}}=7.0 \mathrm{~Hz}\right.$, $\left.\mathrm{CH}\left(\mathrm{CH}_{3}\right)_{2}\right), 1.02 \mathrm{ppm}\left(\mathrm{d}, 6 \mathrm{H}, \mathrm{J}_{\mathrm{HH}}=7.0 \mathrm{~Hz}, \mathrm{CH}\left(\mathrm{CH}_{3}\right)_{2}\right)$. The ${ }^{1} \mathrm{H}$ NMR spectrum did not show any detectable Mo(V) byproduct. Yellow-orange single crystals suitable for x-ray diffraction were grown by slowly cooling a hot saturated heptane solution to room temperature.

\section{Attempted synthesis of Dioxodi- $\mu$-oxobis(tetraisopropylcyclopentadienyl)dimolybdenum(V), $\left[{ }^{4} \mathrm{CpMoO}_{2}\right]_{2}$.}

Compound ${ }^{4} \mathrm{CpMoCl}_{4}(670 \mathrm{mg}, 1.42 \mathrm{mmol})$ was added to $150 \mathrm{ml}$ of a stirred 1:1 mixture of acetone and distilled water, yielding immediately a brown suspension. The mixture was stirred for 40 hours, during which aliquots were withdrawn, the solid was separated, washed with water, and investigated by ${ }^{1} \mathrm{H}$ NMR, showing the spectrum of ${ }^{4} \mathrm{Cp}_{2} \mathrm{Mo}_{2} \mathrm{O}_{5}$ as the only NMR active species. The final mixture was filtered and the solid was washed with water and redissolved in pentane. After evaporation of the solvent, the residue was dried in vacuo leaving $240 \mathrm{mg}(0.33 \mathrm{mmol}$; $46.8 \%$ ) of ${ }^{4} \mathrm{Cp}_{2} \mathrm{Mo}_{2} \mathrm{O}_{5}$ as a orange powder (confirmed by ${ }^{1} \mathrm{H} \mathrm{NMR}$ ). Orange-red crystals could be grown by slowly cooling a hot saturated heptane solution to room temperature or by cooling a pentane solution to $-25{ }^{\circ} \mathrm{C}$. A single crystal from this batch showed the same unit cell as that of the yellow-orange crystals obtained from the procedure in the previous section.

\section{Tetraoxo- $\mu$-oxobis(1,2,4-tri-tert-butylcyclopentadienyl)dimolybdenum(VI), Cp"' $2 \mathrm{Mo}_{2} \mathrm{O}_{5}$ and Dioxodi- $\mu$ -} oxobis(pentamethylcyclopentadienyl)dimolybdenum(V), $\left[\mathbf{C p}^{\prime \prime \prime} \mathbf{M o O}_{2}\right]_{2}$. To a stirred mixture of THF (75 mL), acetone $(75 \mathrm{~mL})$, water $(10 \mathrm{~mL})$ and aqueous $\mathrm{NaOH}(5.7 \mathrm{~mL}, 3 \mathrm{M}, 17.1 \mathrm{mmol})$ in an open beaker was added purple $\mathrm{Cp}^{\prime \prime} \mathrm{MoCl}_{4}(1.36 \mathrm{~g}, 2.89 \mathrm{mmol})$. Some foaming occurred and a bordeaux-red solution formed immediately. No precipitate was detected during the following 24 hours of stirring at room temperature. Subsequent gentle heating (40$50{ }^{\circ} \mathrm{C}$ ) of the mixture for two hours caused the precipitation of a red-violet product, which was collected on a filter, washed with water, redissolved in THF and evaporated to dryness leaving the Mo(V) dimer $\left[\left(\mathrm{Cp}^{\prime \prime} \mathrm{MoO}_{2}\right)_{2}\right]$ as the main product. Yield: $380 \mathrm{mg}(0.53 \mathrm{mmol}, 36.7 \%)$. Elem. anal. Calcd for $\mathrm{C}_{17} \mathrm{H}_{29} \mathrm{MoO}_{2}$ : C, 56.51; H, 8.09\%. Found: C, 56.72; H, $8.12 \%$. IR (Nujol mull): 922s, 885s, 764vs cm ${ }^{-1} .{ }^{1} \mathrm{H}$ NMR $\left(\mathrm{C}_{6} \mathrm{D}_{6}\right): 6.43 \mathrm{ppm}(\mathrm{s}, 2 \mathrm{H}$, ring-H), $1.46 \mathrm{ppm}(\mathrm{s}$, $18 \mathrm{H}, \mathrm{CMe}_{3}$ 1,2-positions), $1.37 \mathrm{ppm}$ (s, 9H, $\mathrm{CMe}_{3}$ 4-position). Suitable single crystals were grown by slowly cooling a hot saturated heptane solution to room temperature.

The orange-yellow filtrate was collected and evaporated to dryness. The resulting yellow residue was extracted with 70 $\mathrm{ml}$ of distilled water and the extract was acidified with diluted glacial acetic acid to $\mathrm{pH} 4$, as described above for the $\mathrm{Cp}^{*}$ analogue. The yellow solid which precipitated was extracted with several portions of ether and the combined organic layers $(300 \mathrm{ml})$ were washed with $200 \mathrm{ml}$ of distilled water and dried over $\mathrm{MgSO}_{4}$. The shiny yellow ether phase was allowed to stay overnight and was then evaporated to dryness, yielding $120 \mathrm{mg}(0,16 \mathrm{mmol} .11 .2 \%)$ of yellow [ $\left.\left(\mathrm{Cp}^{\prime \prime \prime} \mathrm{MoO}_{2}\right)_{2} \mathrm{O}\right]$. Elem. anal. Calcd for $\mathrm{C}_{34} \mathrm{H}_{58} \mathrm{Mo}_{2} \mathrm{O}_{5}$ : C, 55.28; H, $7.91 \%$. Found: C, 55.04; H, 7.94 \%. ${ }^{1} \mathrm{H}$ NMR ( $\left.\mathrm{C}_{6} \mathrm{D}_{6}\right): 5.63$ ppm (s, 2H, ring-H), 1.58 ppm (18H, $\mathrm{CMe}_{3}$ 1,2-position), 1.48 ppm (9H, CMe ${ }_{3}^{4}$-position). Suitable single crystals were grown by slowly cooling a hot saturated heptane solution to room temperature.

Alternative route to pure $\mathbf{C p}{ }_{2} \mathbf{M o}_{2} \mathbf{O}_{5}$. Acetone $(120 \mathrm{~mL})$ was mixed with an aqueous $\mathrm{NaOH}$ solution $(6.6 \mathrm{~mL}, 3 \mathrm{M}$, $19.8 \mathrm{mmol})$. Purple $\mathrm{Cp}^{\prime \prime} \mathrm{MoCl}_{4}(1.55 \mathrm{~g}, 3.29 \mathrm{mmol})$ was added causing a deep red solution followed by slow turning of the supernatant to orange with formation of a white yellow precipitate within a $3 \mathrm{~h}$ period. After stirring overnight all solvents were evaporated under reduced pressure and the yellowish residue was extracted with $100 \mathrm{~mL}$ of water and layered with $100 \mathrm{~mL}$ of ether. The ether layer remained colorless until the aqueous one was acidified with diluted acetic 
acid, causing the formation of a shiny yellow precipitate, which was extracted by the ether. After addition of the last traces of acid, which led to further precipitation, the aqueous phase was clear and colorless. The ether phases was washed three times with distilled water and dried over $\mathrm{MgSO}_{4}$ overnight. Evaporation to dryness gave $890 \mathrm{mg}$ (1.20 mmol, $73.2 \%$ ) of orange-yellow $\mathrm{Cp}^{\prime \prime}{ }_{2} \mathrm{Mo}_{2} \mathrm{O}_{5}$ without any detectable $\mathrm{Mo}(\mathrm{V})$ by-product.

Chlorodioxo(tetraisopropylcyclopentadienyl)molybdenum(VI), ${ }^{4} \mathbf{C p M o O} \mathbf{M}_{2} \mathbf{C l}$. Aqueous $\mathrm{NaOH}(2.89 \mathrm{ml}, 3 \mathrm{M}, 8.67$ mmol) was added to $250 \mathrm{ml}$ of acetone. After addition of solid ${ }^{4} \mathrm{CpMoCl}_{4}(1.362 \mathrm{~g}, 2.89 \mathrm{mmol})$ the solution turned red forming a white precipitate. Stirring overnight changed the color of the supernatant to a bright yellow-orange. All solvents were removed in vacuo leaving a yellow residue which was extracted with $200 \mathrm{ml}$ of pentane. This pentane solution was dried over $\mathrm{Na} 2 \mathrm{SO} 4$, filtered and evaporated to dryness leaving $1.0 \mathrm{~g}$ of a yellow-orange solid (2.52 mmol, $87 \%)$, which was then recrystallized from a saturated heptane solution at $-30{ }^{\circ} \mathrm{C}$. Elem. anal. Calcd for $\mathrm{C}_{17} \mathrm{H}_{29} \mathrm{ClMoO}_{2}: \mathrm{C}, 51.45 ; \mathrm{H}$,

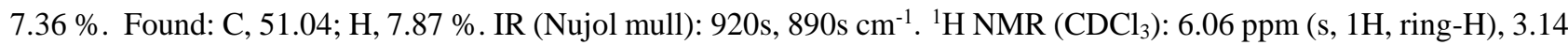
$\operatorname{ppm}(\mathrm{m}, 4 \mathrm{H}, \mathrm{CHMe} 2), 1.40 \mathrm{ppm}\left(\mathrm{d}, 6 \mathrm{H}, \mathrm{J}_{\mathrm{HH}}=7.4 \mathrm{~Hz}, \mathrm{CH}\left(\mathrm{CH}_{3}\right)_{2}\right), 1.35 \mathrm{ppm}\left(\mathrm{d}, 6 \mathrm{H}, \mathrm{J}_{\mathrm{HH}}=7.3 \mathrm{~Hz}, \mathrm{CH}(\mathrm{CH})_{2}\right), 1.31 \mathrm{ppm}$ $\left(\mathrm{d}, 6 \mathrm{H}, \mathrm{J}_{\mathrm{HH}}=6.7 \mathrm{~Hz}, \mathrm{CH}\left(\mathrm{CH}_{3}\right)_{2}\right), 1.25 \mathrm{ppm}\left(\mathrm{d}, 6 \mathrm{H}, \mathrm{J}_{\mathrm{HH}}=7.0 \mathrm{~Hz}, \mathrm{CH}\left(\mathrm{CH}_{3}\right)_{2}\right)$. A suitable single crystal for the X-ray analysis was grown by slowly cooling a hot saturated heptane solution to room temperature. The same reaction was found to take place with just two equivalents of $\mathrm{NaOH}$ used, yielding the same product in an identical overall yield.

X-ray Crystallographic Study: The crystal and refinement parameters for all structures are collected in Table 4 . All set of data were collected on an Enraf-Nonius KappaCCD diffractometer at $110 \mathrm{~K}$ using Mo Ka radiation. The structures were solved via a Patterson search program ${ }^{[48]}$ and refined with full-matrix least-squares methods ${ }^{[49]}$ based on $\left|\mathrm{F}^{2}\right|$ with the aid of the WINGX program. ${ }^{[50]}$ All non-hydrogen atoms were refined with anisotropic thermal parameters. Hydrogen atoms were located on final Fourier difference maps and freely refined with isotropic temperature factors fixed to 1.2 or 1.5 (for $\mathrm{CH}_{3}$ ) times those of the corresponding parent atoms. Selected bond distances and angles are listed in Table 1 for both independent molecules of ${ }^{4} \mathrm{Cp}_{2} \mathrm{Mo}_{2} \mathrm{O}_{5}$ and for $\mathrm{Cp}^{\prime \prime}{ }_{2} \mathrm{Mo}_{2} \mathrm{O}_{5}$, in Table 2 for for $\left[\mathrm{Cp}^{\prime \prime} \mathrm{MoO}_{2}\right]_{2}$, and in Table 3 for ${ }^{4} \mathrm{CpMoO}_{2} \mathrm{Cl}$. Crystallographic data (excluding structure factors) for the structures reported in this paper have been deposited with the Cambridge Crystallographic Data Centre as supplementary publication no. CCDC-173139-173143. Copies of the data can be obtained free of charge on application to CCDC, 12 Union Road, Cambridge CB2 1EZ, UK [Fax: (internat.) + 44-1223/336-033; Email: deposit@ccdc.cam.ac.uk]. 
Table 4. Crystal data and structure refinement for all compounds.

\begin{tabular}{|c|c|c|c|c|c|}
\hline Compound & ${ }^{4} \mathrm{Cp}_{2} \mathrm{Mo}_{2} \mathrm{O}_{5}, \quad 1$ & $\mathrm{Cp}^{\prime \prime \prime}{ }_{2} \mathrm{MO}_{2} \mathrm{O}_{5}, \quad 2$ & $\mathrm{Cp}^{*}{ }_{2} \mathrm{MO}_{2} \mathrm{O}_{4}, \quad 3$ & {$\left[\mathrm{Cp}^{\prime \prime \prime} \mathrm{MoO}_{2}\right]_{2}, \mathbf{4}$} & ${ }^{4} \mathrm{CpMOO}_{2} \mathrm{Cl}, \quad 5$ \\
\hline Formula & $\mathrm{C}_{34} \mathrm{H}_{58} \mathrm{MO}_{2} \mathrm{O}_{5}$ & $\mathrm{C}_{34} \mathrm{H}_{58} \mathrm{MO}_{2} \mathrm{O}_{5}$ & $\mathrm{C}_{20} \mathrm{H}_{30} \mathrm{MO}_{2} \mathrm{O}_{4}$ & $\mathrm{C}_{34} \mathrm{H}_{58} \mathrm{MO}_{2} \mathrm{O}_{4}$ & $\mathrm{C}_{17} \mathrm{H}_{29} \mathrm{Cl} \mathrm{MOO}_{2}$ \\
\hline M & 738.68 & 738.68 & 526.32 & 722.68 & 396.79 \\
\hline $\mathrm{T} ; \mathrm{K}$ & $110(2)$ & $110(2)$ & $110(2)$ & $110(2)$ & $110(2)$ \\
\hline Crystal system & monoclinic & monoclinic & tetragonal & triclinic & monoclinic \\
\hline Space group & $\mathrm{P} 2{ }_{1} / \mathrm{C}$ & $\mathrm{P} 2{ }_{1} / \mathrm{C}$ & $P-42_{1} C$ & $\mathrm{P}-1$ & $\mathrm{P} 2{ }_{1} / \mathrm{C}$ \\
\hline $\mathrm{a} ; \AA$ & $11.8993(2)$ & $14.8025(2)$ & $11.5418(9)$ & $10.3976(1)$ & $8.8290(2)$ \\
\hline $\mathrm{b} ; \AA$ & $20.0429(3)$ & $10.3088(1)$ & $11.5418(9)$ & $11.9801(2)$ & $12.3811(3)$ \\
\hline C; $\AA$ & $14.7150(2)$ & $23.6064(3)$ & $15.3875(3)$ & $14.0109(2)$ & $17.1372(6)$ \\
\hline$\alpha ;{ }^{\circ}$ & 90 & 90 & 90 & $84.658(1)$ & 90 \\
\hline$\beta ; \circ$ & $95.597(1)$ & $107.226(1)$ & 90 & $88.904(1)$ & $103.690(1)$ \\
\hline$\gamma, \circ$ & 90 & 90 & 90 & $88.898(1)$ & 90 \\
\hline $\mathrm{V} ; \AA^{3}$ & $3492.74(9)$ & $3440.66(7)$ & $2049.8(2)$ & $1737.09(4)$ & $1820.09(9)$ \\
\hline z & 4 & 4 & 4 & 2 & 4 \\
\hline$F(000)$ & 1544 & 1544 & 1064 & 756 & 824 \\
\hline $\mathrm{D}_{\text {calc }} ; \mathrm{g} / \mathrm{cm}^{3}$ & 1.405 & 1.426 & 1.705 & 1.382 & 1.448 \\
\hline $\begin{array}{l}\text { Diffract., scan type } \\
\lambda ; \AA\end{array}$ & & Kappa & $\begin{array}{r}\text { D, mixture of } \phi \\
0.71\end{array}$ & $\begin{array}{l}\text { rotations and } \omega \\
73\end{array}$ & scans \\
\hline$\mu ; \mathrm{mm}^{-1}$ & 0.755 & 0.766 & 1.245 & 0.755 & 0.870 \\
\hline $\begin{array}{l}\text { Crystal size; } \mathrm{mm}^{3} \\
\sin (\theta) / \lambda \max ; \AA^{-1}\end{array}$ & $\begin{array}{l}0.30 \times 0.25 \times 0.13 \\
0.65\end{array}$ & $\begin{array}{l}0.43 \times 0.25 \times 0.25 \\
0.65\end{array}$ & $\begin{array}{l}0.20 \times 0.20 \times 0.12 \\
0.65\end{array}$ & $\begin{array}{l}0.32 \times 0.25 \times 0.20 \\
0.65\end{array}$ & $\begin{array}{l}0.25 \times 0.15 \times 0.08 \\
0.69\end{array}$ \\
\hline Index ranges & $\begin{array}{l}\mathrm{h}:-15 ; 15 \\
\mathrm{k}:-25 ; 26 \\
\mathrm{l}:-19 ; 19\end{array}$ & $\begin{array}{l}\mathrm{h}:-19 ; 19 \\
\mathrm{k}:-13 ; 12 \\
\mathrm{l}:-30 ; 30\end{array}$ & $\begin{array}{ll}\mathrm{h}:-12 ; & 14 \\
\mathrm{k}:-14 ; & 13 \\
\mathrm{l}:-19 ; & 18\end{array}$ & $\begin{array}{l}\mathrm{h}:-12 ; 13 \\
\mathrm{k}:-15 ; 15 \\
\mathrm{l}:-18 ; 18\end{array}$ & $\begin{array}{llr}\mathrm{h}: & -12 ; & 6 \\
\mathrm{k}: & -16 ; & 15 \\
\mathrm{l}: & -21 ; & 23\end{array}$ \\
\hline $\mathrm{RC}=\operatorname{Refl}$. Collected & 25939 & 22209 & 10012 & 13541 & 8953 \\
\hline IRC = unique $\mathrm{RC} / \mathrm{R}$ (int) & $7990 / 0.0403$ & $7828 / 0.0243$ & $2317 / 0.0284$ & $7847 / 0.0141$ & $4530 / 0.0190$ \\
\hline $\operatorname{IRCGT}=\operatorname{IRC}$ and $[I>2 \sigma(I)]$ & 5940 & 6728 & 2198 & 7073 & 3952 \\
\hline Refinement method & & & Full-matrix & L.S. on $F^{2}$ & \\
\hline $\begin{array}{l}\text { Data / restr. / param. } \\
\text { R for IRCGT }\end{array}$ & $\begin{array}{l}7990 / 0 / 545 \\
R 1^{a}=0.0291 \\
\mathrm{WR} 2^{b}=0.0594\end{array}$ & $\begin{array}{l}7828 / 0 / 545 \\
R 1^{a}=0.0241 \\
\mathrm{WR} 2^{b}=0.0520\end{array}$ & $\begin{array}{l}2317 / 0 / 164 \\
\mathrm{R}^{\mathrm{a}}=0.0213 \\
\mathrm{WR} 2^{\mathrm{b}}=0.0455\end{array}$ & $\begin{array}{l}7847 / 0 / 535 \\
\mathrm{R}^{\mathrm{a}}=0.0215 \\
\mathrm{WR} 2^{\mathrm{b}}=0.0519\end{array}$ & $\begin{array}{l}4530 / 0 / 277 \\
\mathrm{R}^{\mathrm{a}}=0.0215 \\
\mathrm{WR} 2^{\mathrm{b}}=0.0762\end{array}$ \\
\hline$R$ for IRC & $\begin{array}{l}\mathrm{R} 1^{\mathrm{a}}=0.0507 \\
\mathrm{WR} 2^{\mathrm{b}}=0.0650\end{array}$ & $\begin{array}{l}\mathrm{R} 1^{\mathrm{a}}=0.0324 \\
\mathrm{WR} 2^{\mathrm{b}}=0.0548\end{array}$ & $\begin{array}{l}\mathrm{R} 1^{\mathrm{a}}=0.0238 \\
\mathrm{WR} 2^{\mathrm{b}}=0.0465\end{array}$ & $\begin{array}{l}\mathrm{R} 1^{\mathrm{a}}=0.0255 \\
\mathrm{WR} 2^{\mathrm{b}}=0.0539\end{array}$ & $\begin{array}{l}\mathrm{R} 1^{\mathrm{a}}=0.0403 \\
\mathrm{WR} 2^{\mathrm{b}}=0.0793\end{array}$ \\
\hline Flack param. & - & - & $0.00(4)$ & - & - \\
\hline Goodness-of-fitc & 1.034 & 0.975 & 1.055 & 1.046 & 1.039 \\
\hline$\Delta \rho, \max , \min ; e . \AA^{-3}$ & $0.571,-0.478$ & $0.438,-0.499$ & $0.324,-0.601$ & $0.422,-0.620$ & $1.090,-0.894$ \\
\hline
\end{tabular}

${ }^{\mathrm{a}} \mathrm{R} 1=\Sigma\left(|| \mathrm{F}_{\mathrm{o}}|-| \mathrm{F}_{\mathrm{c}} \mid\right) / \Sigma\left|\mathrm{F}_{\mathrm{o}}\right|{ }^{\mathrm{b}} \mathrm{wR} 2=\left[\Sigma \mathrm{w}\left(\mathrm{F}_{\mathrm{o}}{ }^{2}-\mathrm{F}_{\mathrm{c}}{ }^{2}\right)^{2} / \Sigma\left[\mathrm{w}\left(\mathrm{F}_{\mathrm{o}}{ }^{2}\right)^{2}\right]^{1 / 2}\right.$ where $\mathrm{w}=1 /\left[\sigma^{2}\left(\mathrm{Fo}^{2}+(\mathrm{aP})^{2}+\mathrm{bP}\right]\right.$ and $\mathrm{P}=\left(\mathrm{Max}\left(\mathrm{Fo}^{2}, 0\right)+2 * \mathrm{Fc}^{2}\right) / 3$ where $(\mathrm{a}, \mathrm{b})=(0.028,0.0)$ for 1, $(0.023,1.69)$ for 2 , $(0.26,0.0)$ for $\mathbf{3},(0.018,0.79)$ for $\mathbf{4}$ and $(0.024,2.22)$ for $\mathbf{5}$. 


\section{Acknowledgments}

We are grateful to the Ministère de la Recherche and the CNRS for general support through UMR 5632 and the French and German Ministeries of Foreign Affairs for a bilateral Procope grant. DS thanks the Conseil Régional de Bourgogne for a post-doctoral fellowship and FD thanks the Scientific and Technical Research Council of Turkey (TUBITAK) for a NATO Science Fellowship Programme scholarship, and Celal Bayar University for a leave of absence.

\section{References}

[1] W. A. Herrmann, Comments Inorg. Chem. 1988, 7, 73-107.

[2] W. A. Herrmann, Angew. Chem., Int. Ed. Engl. 1988, 27, 1297-1313.

[3] W. A. Herrmann, F. E. Kühn, Acc. Chem. Res. 1997, 30, 169-180.

[4] M. Cousins, M. L. H. Green, J. Chem. Soc. 1964, 1567-1572.

[5] M. Cousins, M. L. H. Green, J. Chem. Soc. (A) 1969, 16-19.

[6] R. H. Holm, Chemical Reviews 1987, 87, 1401-1449.

[7] D. T. Richens, in The Chemistry of Aqua Ions, J. Wiley \& Sons, Chichester, 1997, pp. 259-336.

[8] G. Wilkinson, F. G. A. Stone, E. W. Abel, Comprehensive Organometallic Chemistry, Pergamon, Oxford, 1982.

[9] E. W. Abel, F. G. Stone, G. Wilkinson, Comprehensive Organometallic Chemistry II, Vol. 8, Pergamon, Oxford, 1995.

[10] E. Collange, J. Garcia, R. Poli, submitted for publication.

[11] J. Gun, A. Modestov, O. Lev, D. Saurenz, M. Vorotyntsev, R. Poli, submitted for publication.

[12] M. J. Bunker, M. L. H. Green, J. Chem. Soc., Dalton Trans. 1981, 847-851.

[13] P. Legzdins, E. C. Phillips, S. J. Rettig, L. Sánchez, J. Trotter, V. C. Yee, Organometallics 1988, 7, 18771878.

[14] J. W. Faller, Y. Ma, Organometallics 1988, 7, 559-561.

[15] J. W. Faller, Y. Ma, J. Organomet. Chem. 1989, 368, 45-56.

[16] M. B. Trost, R. G. Bergman, Organometallics 1991, 10, 1172-1178.

[17] D. Chakraborty, M. Bhattacharjee, R. Krätzner, R. Siefken, H. W. Roesky, I. Usón, H.-G. Schmidt, Organometallics 1999, 18, 106-108.

[18] H. J. Lucas, E. R. Kennedy, M. W. Formo, Org. Synth. 1942, 22, 483-485.

[19] J. C. Gordon, R. Poli, in Synthetic Methods of Organometallic and Inorganic Chemistry (Herrmann/Brauer), Vol. 8 (Ed.: W. A. Herrmann), Georg Thieme Verlag, Stuttgart, 1997, pp. 97-98.

[20] Studies aimed at the identification of this anion are currently underway in our laboratory.

[21] M. Herberhold, W. Kremnitz, A. Razavi, H. Schöllhorn, U. Thewalt, Angew. Chem. Int. Ed. Engl. 1985, 24, 601-602.

[22] K. Isobe, S. Kimura, Y. Nakamura, J. Organometal. Chem. 1987, 331, 221-228.

[23] P. Gomez-Sal, E. de Jesus, P. Royo, A. Vazquez de Miguel, S. Martinez-Carrera, S. Garcia-Blanco, J. Organometal. Chem. 1988, 353, 191-196.

[24] P. Leoni, M. Pasquali, L. Salsini, C. di Bugno, D. Braga, P. Sabatino, J. Chem. Soc. Dalton Trans. 1989, 155159.

[25] A. L. Rheingold, J. R. Harper, J. Organometal. Chem. 1991, 403, 335-344.

[26] J. W. Faller, Y. Ma, J. Organometal. Chem. 1988, 340, 59-69.

[27] R. B. King, M. B. Bisnette, J. Organometal. Chem. 1967, 8, 287-297.

[28] C. D. Abernethy, F. Bottomley, J. Chen, M. F. Kemp, T. C. Mallais, O. O. Womiloju, Inorg. Synth. 1998, 32, 207-214.

[29] F. Bottomley, J. Chen, Organometallics 1992, 11, 3404-3411.

[30] F. Bottomley, P. D. Boyle, J. H. Chen, Organometallics 1994, 13, 370-373.

[31] K. Umakoshi, K. Isobe, J. Organometal. Chem. 1990, 395, 47-53.

[32] J. Sundermeyer, U. Radius, C. Burschka, Chem. Ber. 1992, 125, 2379-2384.

[33] M. S. Rau, C. M. Kretz, L. A. Mercando, G. L. Geoffroy, A. L. Rheingold, J. Am. Chem. Soc. 1991, 113, 7420-7421.

[34] M. S. Rau, C. M. Kretz, G. L. Geoffroy, A. L. Rheingold, Organometallics 1993, 12, 3447-3460.

[35] On the other hand, it is interesting to note that the use of excess aqueous $\mathrm{NaOH}$ in the hydrolysis reaction of $\mathrm{Cp}^{*} \mathrm{WCl}_{4}$ did not induce displacement of the residual chloride ligand in $\mathrm{Cp}^{*} \mathrm{WO}_{2} \mathrm{Cl}^{[34]}$ 
[36] In reality, the aqueous behavior is even more complex and interesting. A detailed study of the aqueous speciation of the $\mathrm{Cp}^{*} \mathrm{Mo}^{\mathrm{VI}}$ system in the entire $\mathrm{pH}$ range will be the topic of a separate report. ${ }^{[10]}$

[37] D. W. Keogh, R. Poli, in Synthetic Methods of Organometallic and Inorganic Chemistry (Herrmann/Brauer), Vol. 8 (Ed.: W. A. Herrmann), Georg Thieme Verlag, Stuttgart, 1997, p. 98.

[38] H. Arzoumanian, A. Baldy, M. Pierrot, M. Petrignani, J. Organometal. Chem. 1985, 294, 327-331.

[39] C. Couldwell, K. Prout, Acta Crystallographica 1978, B34, 933-934.

[40] E. de Jesus, A. Vazquez de Miguel, P. Royo, A. M. M. Lanfredi, A. Tiripicchio, J. Chem. Soc., Dalton Trans. 1990, 2779-2784.

[41] M. Hahn, K. Wieghardt, Inorganic Chemistry 1984, 23, 3977-3982.

[42] K. Wieghardt, M. Guttmann, P. Chaudhuri, W. Gebert, M. Minelli, C. G. Young, J. H. Enemark, Inorg. Chem. 1985, 24, 3151-3155.

[43] W. M. Harrison, C. Saadeh, S. B. Colbran, D. C. Craig, J. Chem. Soc., Dalton Trans. 1997, 3785-3792.

[44] R. Siefken, M. Teichert, D. Chakraborty, H. W. Roesky, Organometallics 1999, 18, 2321-2325.

[45] F. Bottomley, E. C. Ferris, P. S. White, Organometallics 1990, 9, 1166-1171.

[46] J. M. B. Blanchard, Q. Chen, Y.-D. Chang, M. B. Sponsler, Inorg. Chim. Acta 1994, 221, 147-150.

[47] M. Bastian, D. Morales, R. Poli, P. Richard, H. Sitzmann, submitted for publication.

[48] G. M. Sheldrick, SHELXS97. Program for Crystal Structure solution, University of Göttingen, Göttingen, Germany, 1997.

[49] G. M. Sheldrick, SHELXL97. Program for Crystal Structure refinement, University of Göttingen, Göttingen, Germany, 1997.

[50] L. J. Farrugia, J. Appl. Crystallogr. 1999, 32, 837-838. 


\section{Graphical Abstract}

Improved syntheses are reported for compounds $\mathrm{Cp}_{2} \mathrm{Mo}_{2} \mathrm{O}_{5}$ and $\mathrm{Cp}^{*}{ }_{2} \mathrm{Mo}_{2} \mathrm{O}_{5}$. Extension of these procedures have yielded homologues with sterically more encumbering cyclopentadienyl rings and related compounds, some of which have been structurally characterized. 